\title{
Cationic Platinum(II) $\sigma$-SiH Complexes in Carbon Dioxide Hydrosilation
}

\author{
Pablo Ríos, ${ }^{[a]}$ Josefina Díez, ${ }^{[b]}$ Joaquín López-Serrano, ${ }^{[a]}$ Amor Rodríguez ${ }^{*[a]}$ and Salvador Conejero*[a]
}

Dedication ((optional))

\begin{abstract}
The low electron count cationic platinum complex $\left[\mathrm{Pt}\left(\mathrm{I}^{t} \mathrm{Bu}{ }^{\prime}\right)\left({ }^{t} \mathrm{Bu}\right)\right]\left[\mathrm{BAr}{ }^{\mathrm{F}}\right], \mathbf{1}$, interacts with primary and secondary silanes to form the corresponding $\sigma-\mathrm{SiH}$ complexes. According to DFT calculations the most stable coordination mode is the uncommon $\eta^{1}$ $\mathrm{SiH}$. The reaction of $\mathbf{1}$ with $\mathrm{Et}_{2} \mathrm{SiH}_{2}$ leads to the X-ray structurally characterized 14-electron $\mathrm{Pt}^{\prime \prime}$ species $\left[\mathrm{Pt}\left(\mathrm{SiEt}_{2} \mathrm{H}\right)\left({ }^{t} \mathrm{Bu}\right)_{2}\right]\left[\mathrm{BAr}{ }^{\mathrm{F}}\right], 2$, that is stabilized by an agostic interaction. Complexes 1, 2 and the hydride $\left[\mathrm{Pt}(\mathrm{H})\left(\mathrm{I}^{\mathrm{t}} \mathrm{Bu}\right)_{2}\right]\left[\mathrm{BAr}{ }^{\mathrm{F}}\right]$, 3, catalyze the hydrosilation of $\mathrm{CO}_{2}$ leading to the exclusive formation of the corresponding silyl formates at room temperature.
\end{abstract}

Silane $\sigma$-complexes lie at the very heart of numerous catalytic transformations ${ }^{[1]}$ Coordination of the $\mathrm{Si}-\mathrm{H}$ bond of a silane to a coordinatively unsaturated metal center in either $\eta^{1}-, \eta^{2}$ - or even $\eta^{3}$-fashion (Figure 1) enhances the electrophilicity at silicon making it susceptible of nucleophilic attack to form new Si-X bonds $(\mathrm{X}=\mathrm{O}, \mathrm{N}, \mathrm{C}$, etc), and in some cases transferring one of its hydrides to the metal atom. ${ }^{[2]}$ On the other hand, isolation or even

$$
\mathrm{M}-\mathrm{H}-\mathrm{SiR}_{3}
$$$$
\mathrm{M} \stackrel{\mathrm{H}}{\stackrel{\mathrm{I}}{\mathrm{SiR}_{3}}}
$$

$\eta^{1}$-silane complex $\eta^{2}$-silane complex

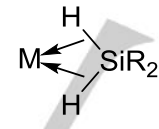

$\eta^{3}$-silane complex
Figure 1. Coordination modes of silanes.

observation (by spectroscopic means) of silane $\sigma-\mathrm{SiH}$ species in cationic transition metal complexes is still rare, ${ }^{[2 \mathrm{~d}, \mathrm{e} ; 3]}$ with no examples in platinum chemistry. While in most of the cases $\sigma$ $\mathrm{SiH}$ compounds have been formed as transient species in hydrosilation processes, and other catalytic reactions, their role in $\mathrm{CO}_{2}$ hydrosilation have been barely studied. ${ }^{[4]}$ In this sense, the catalytic reduction of carbon dioxide into more valuable compounds is gaining relevance. ${ }^{[5]}$ However, its high thermodynamic stability is an important drawback. Some research groups have made use of hydrosilanes to overcome

[a] P. Ríos, Dr. J. López-Serrano, Dr. A Rodríguez, Dr. S. Conejero Instituto de Investigaciones Químicas (IIQ), Departamento de Química Inorgánica, Centro de Innovación en Química Avanzada (ORFEO-CINCA)

CSIC and Universidad de Sevilla

Avda. Américo Vespucio 49, 41092 Sevilla, Spain

E-mail: marodriguez@iiq.csic.es; sconejero@iiq.csic.es

[b] Dr. J. Díez

Laboratorio de Compuestos Organometálicos y Catálisis

(Unidad asociada al CSIC), Departamento de Química Orgánica e Inorgánica

Universidad de Oviedo

C/Julián Clavería 8, 33006, Oviedo, Spain

Supporting information for this article is given via a link at the end of

the document.((Please delete this text if not appropriate)) unfavorable thermodynamics in the reduction of $\mathrm{CO}_{2}$ to formate, ${ }^{[4 c, d ; 6]}$ acetal, ${ }^{[7]}$ methoxy ${ }^{[8]}$ and even methane levels (Figure 2). ${ }^{[4 a, 9]}$ Controlling the selectivity of the reaction to generate a single product is particularly challenging. Brookhart et al. reported that the iridium $\eta^{1}-\mathrm{SiH}$ complex $\left[(\mathrm{POCOP}) \operatorname{Ir}(\mathrm{H})\left(\eta^{1}\right.\right.$ $\left.\left.\mathrm{HSiR}_{3}\right)\right]\left[\mathrm{B}\left(\mathrm{C}_{6} \mathrm{~F}_{5}\right)_{4}\right]$ catalyzes the conversion of $\mathrm{CO}_{2}$ into methane. ${ }^{[4 a]}$ The reaction was suggested to occur through activation of the $\mathrm{Si}-\mathrm{H}$ bond by the electrophilic iridium complex leading to a transient "silylium" cation that is sufficiently reactive towards $\mathrm{CO}_{2}$. In fact, Müller and co-workers have demonstrated the role of silyl cations in the reduction of carbon dioxide. ${ }^{[10]}$ Brookhart's system seems to act in part as a mere Lewis acid, in analogy to other Lewis acids based on main group elements, particularly boron. ${ }^{[11]}$

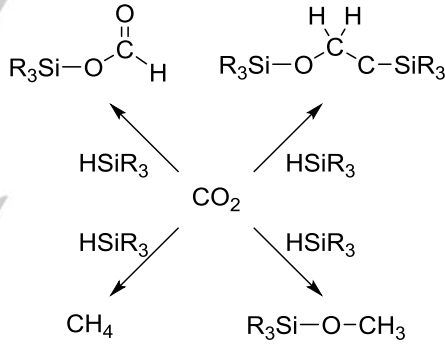

Figure 2. Possible reduction products of $\mathrm{CO}_{2}$ with hydrosilanes

Earlier, we have shown that the platinum(II) complex $\left[\mathrm{Pt}\left(\mathrm{I}^{t} \mathrm{Bu} \mathrm{u}^{\prime}\right)\left(\mathrm{I}^{t} \mathrm{Bu}\right)\right]\left[\mathrm{BAr} \mathrm{F}^{\mathrm{F}}\right] \mathbf{1},{ }^{[12]}$ behaves as a highly electrophilic metal in the dehydrogenation of amine-boranes. ${ }^{[13]}$ In this case, the metal is able to abstract a hydrogen atom from the borane leading to a neutral platinum species $\left[\mathrm{Pt}(\mathrm{H})\left(\mathrm{I}^{t} \mathrm{Bu} \mathrm{u}^{\prime}\right)\left({ }^{t} \mathrm{Bu}\right)\right]$ and a boronium cation, a process that takes place through the intermediacy of $\eta^{1}-\mathrm{BH}$ complexes. Thus, we set out to explore the reactivity of $\mathbf{1}$ towards silanes and $\mathrm{CO}_{2}$ keeping in mind that silanes can also transfer a hydride atom in the presence of metal Lewis acids. In this communication we report the catalytic activity of formally 14-electron $\mathrm{Pt}^{\prime \prime}$ complexes in $\mathrm{CO}_{2}$ hydrosilation with primary and secondary silanes. The process takes place through the initial formation of $\mathrm{Pt}^{\prime \prime} \sigma$-silane complexes in which the preferred coordination mode is $\eta^{1}$ according to DFT calculations.

We first analyzed the interaction of silanes with complex $\left[\mathrm{Pt}\left(\mathrm{I}^{t} \mathrm{Bu}{ }^{\prime}\right)\left(\mathrm{I}^{t} \mathrm{Bu}\right)\right]\left[\mathrm{BAr}{ }^{\mathrm{F}}\right], \mathbf{1}$, at different temperatures in an NMR tube (Scheme 1). Triethylsilane, $\mathrm{Et}_{3} \mathrm{SiH}$, proved to be too bulky to detect any interaction with the metal center. On the other hand, diethylsilane, $\mathrm{Et}_{2} \mathrm{SiH}_{2}$ does not show evidence for an interaction at room temperature. According to NMR data, the chemical shift of the $\mathrm{Si}-\mathrm{H}$ protons in the ${ }^{1} \mathrm{H}$ NMR spectrum appeared at the same $\delta$ than in free $\mathrm{Et}_{2} \mathrm{SiH}_{2}$. However, upon cooling the solution at $-60{ }^{\circ} \mathrm{C}$, the $\mathrm{SiH}$ protons shifted up-field, appearing at $c a$. $\delta 2.20$, while the signal vanished in the baseline 
at $-80{ }^{\circ} \mathrm{C}$. This behavior is consistent with the formation of a $\sigma-$ $\mathrm{SiH}$ platinum complex in which fast exchange between terminal

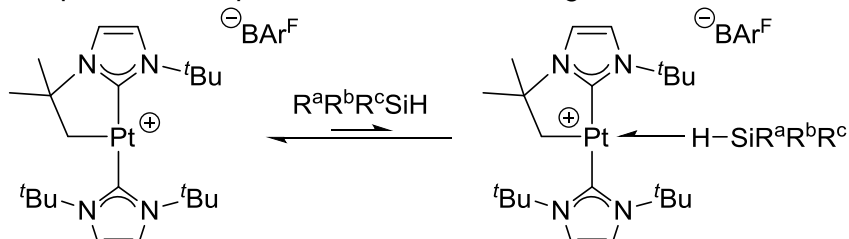

$1 \quad R^{a}=R^{b}=R^{c}=E t\left(1 \cdot\right.$ HSiEt $\left._{3}\right) ;$

$R^{a}=R^{b}=E t, R^{c}=H\left(\mathbf{1} \cdot \mathbf{H}_{2}\right.$ SiEt $\left._{2}\right) ;$

$R^{a}=B u, R^{b}=R^{c}=H\left(1 \cdot H_{3} S i B u\right)$

$R^{a}=P h, R^{b}=R^{c}=H\left(1 \cdot H_{3} S i P h\right)$

$\mathrm{BAr}^{\mathrm{F}}=$ tetrakis[(3,5-trifluoromethyl)phenyl]borate

Scheme 1. Interaction of hydrosilanes with complex 1.

and bridging $\mathrm{Si}-\mathrm{H}$ is taking place. ${ }^{[1 \mathrm{~b}]}$ It should be pointed out that complex 1 rearranges into a new species in the presence of $\mathrm{Et}_{2} \mathrm{SiH}_{2}$ after a few hours (see below) at rt.

When the less hindered primary silane ${ }^{n} \mathrm{BuSiH}_{3}$ was used, the interaction with the platinum atom at room temperature was still too weak to observe a significant change in chemical shifts and coupling constants to platinum. ${ }^{[14]}$ As the temperature decreases the $\mathrm{SiH}$ proton signals are displaced in the ${ }^{1} \mathrm{H}$ NMR spectra to higher field as expected for formation of a $\sigma-\mathrm{SiH}$ complex. The ${ }^{1} \mathrm{H}^{29} \mathrm{Si} \mathrm{HMQC}$ NMR spectrum shows a down-field shift of the resonance of the silicon atom. As a way of an example, at $-50^{\circ} \mathrm{C}$ the $\mathrm{Si}$ atom resonates at ca. $-48 \mathrm{ppm}$, that is, $12 \mathrm{ppm}$ down-field shifted with respect to the free silane $(-60$ ppm). The ${ }^{1} J_{\mathrm{SiH}}$ coupling constant decreases slightly on cooling (see Table S1). At lower temperatures, the fast exchange between bridging and terminal $\mathrm{SiH}$ protons is frozen. At $-65^{\circ} \mathrm{C}$ no signals for these protons are discernible whereas at the lowest temperature of the experiment $\left(-90^{\circ} \mathrm{C}\right)$ two broad signals centered at ca. 4 and -4.4 ppm with relative intensities of $2: 1$ are observed. The broadness of the peaks hampered observation of the corresponding coupling constants with ${ }^{29} \mathrm{Si}$. The presence of cross-peaks between them in a NOESY experiment indicate that these two signals are undergoing exchange on the NMR time scale, thus supporting an structure as depicted in Scheme 1. Phenylsilane $\mathrm{PhSiH}_{3}$ behaves in a similar way to ${ }^{\mathrm{n}} \mathrm{BuSiH}_{3}$, but the dynamic exchange between terminal and bridging hydrogens was not observed even at $-90^{\circ} \mathrm{C}$.

As mentioned above, complex 1 evolves cleanly into two new species in the presence of 1 equiv. $\mathrm{Et}_{2} \mathrm{SiH}_{2}$ at room temperature after a few days. These have been characterized as the low-electron count $\mathrm{Pt}^{\prime \prime}$ silyl derivative $\left[\mathrm{Pt}\left(\mathrm{SiHEt}_{2}\right)\left(\mathrm{I}^{\mathrm{t}} \mathrm{Bu}\right)_{2}\right]\left[\mathrm{BAr}{ }^{\mathrm{F}}\right]$ 2 and the platinum hydride $\left[\mathrm{Pt}(\mathrm{H})\left(\mathrm{I}^{t} \mathrm{Bu}\right)_{2}\right]\left[\mathrm{BAr} \mathrm{F}^{\mathrm{F}}\right], 3,{ }^{[15]}$ (Scheme 2). The reaction can be accelerated by using a large excess (ca. 30 equiv) of $\mathrm{Et}_{2} \mathrm{SiH}_{2}$, which additionally results in an increase of the relative amount of the silyl complex 2 with respect to 3 (typically $\sim 5 \%$ ). Hydrogenation of 1 , by $\mathrm{H}_{2}$ generated by hydrolysis of $\mathrm{Et}_{2} \mathrm{SiH}_{2}$ (catalyzed by 1 ) due to the presence of adventitious water, leads to the formation of $\mathbf{3}$. Importantly, $\mathbf{3}$ does not convert into silyl complex 2 under these experimental conditions.

On the contrary, the reaction of primary silanes ${ }^{n} \mathrm{BuSiH}_{3}$ and $\mathrm{PhSiH}_{3}$ with 1 lead to complex reaction mixtures.
Cationic complex 2 is a rare example of a coordinatively unsaturated $\mathrm{Pt}^{\text {"l }}$ silyl species. This type of compounds

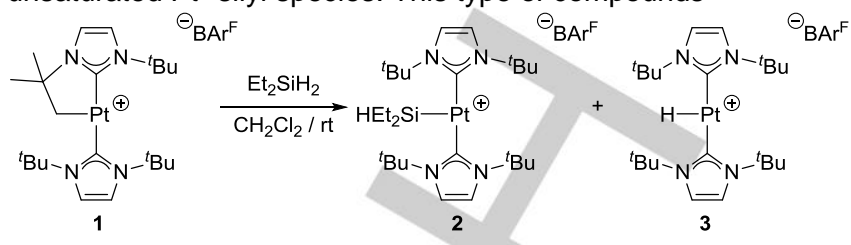

Scheme 2. Formation of complex 2.

has been postulated as intermediates in the generation of silylene species. ${ }^{[16]}$ The $\mathrm{SiH}$ proton resonates in the ${ }^{1} \mathrm{H}$ NMR spectrum as a multiplet centered at $3.64 \mathrm{ppm}$ coupled to ${ }^{195} \mathrm{Pt}$ $\left({ }^{2} J_{\mathrm{Pt}, \mathrm{H}}=115 \mathrm{~Hz}\right)$ consistent with the formulation of 2 as a platinum silyl species. ${ }^{[17]}$ The ${ }^{1} \mathrm{H},{ }^{29} \mathrm{Si}$-HMQC NMR spectrum shows a signal at $18.1 \mathrm{ppm}$ for the silyl group. These experimental observations were further borne out by X-ray diffraction studies (Figure 3 ), which show the platinum atom surrounded by two I ${ }^{t} \mathrm{Bu}$ ligands in a mutually trans disposition and a silyl fragment with no ligand trans to it. One of the $\mathrm{CH}$ bonds of a tert-butyl group is in close proximity to the metal

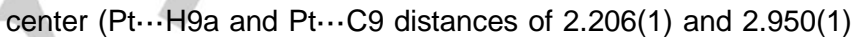
$\AA$ ), suggesting that an agostic interaction is stabilizing the highly electrophilic platinum atom. The angle defined by the two carbenes and the platinum atom (C1-Pt1-C12) deviates from linearity $\left(167.4(3)^{\circ}\right)$ as a consequence of the buttressing effect of the silyl ligand exerted on the NHC that stablishes the agostic interaction. The Pt1-Si1 bond distance of 2.314(3) A falls in the expected region for $\mathrm{Pt}^{\prime \prime}$ silyl species.

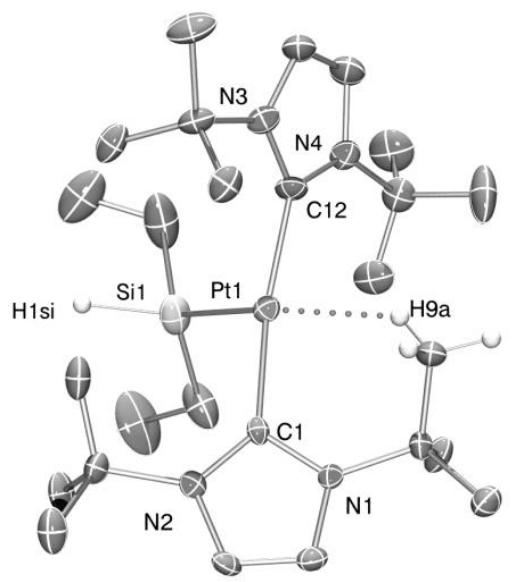

Figure 3. Molecular structure of complex 2 determined by $X$-ray crystallography. $\mathrm{BAr}^{\mathrm{F}}$ anion and most of hydrogen atoms have been omitted for clarity. Ellipsoids are drawn at $30 \%$ probability.

At variance with hydride 3 that was not possible to be isolated in the solid state due to its propensity reform $\mathbf{1}$, cyclometalation of $\mathbf{2}$ with concomitant extrusion of $\mathrm{Et}_{2} \mathrm{SiH}_{2}$ takes place at rt ( $25 \%$ of conversion after 5 days) or under mild heating for a few hours. On the other hand compound 2 does not react with $\mathrm{H}_{2}$ leading to $\mathrm{Et}_{2} \mathrm{SiH}_{2}$ and 3 which contrast with the fast hydrogenation of the cyclometalated species 1 . 
The interaction of ${ }^{n} \mathrm{BuSiH}_{3}$ and $\mathrm{Et}_{2} \mathrm{SiH}_{2}$ with silyl and hydrido derivatives $\mathbf{2}$ and $\mathbf{3}$ was also explored. VT NMR studies have proven that formation of their $\sigma-\mathrm{SiH}$ complexes is less favored than in the case of $\mathbf{1}$. For example, ${ }^{1} \mathrm{H}$ NMR spectra of the silyl species $\left[\mathrm{Pt}\left(\mathrm{SiEt}_{2} \mathrm{H}\right)\left(\mathrm{I}^{\mathrm{t}} \mathrm{Bu}\right)_{2}\right]\left[\mathrm{BAr}{ }^{\mathrm{F}}\right]$ in the presence of 1 equiv of ${ }^{n} \mathrm{BuSiH}_{3}$ shows only a marginally different chemical shift of the $\mathrm{SiH}_{3}$ protons at $-90{ }^{\circ} \mathrm{C}(0.1 \mathrm{ppm}$ downfield shifted with respect to the ${ }^{1} \mathrm{H}$ NMR spectrum recorded at rt). Expectedly, the silicon nucleus of ${ }^{\mathrm{n}} \mathrm{BuSiH} \mathrm{H}_{3}$ resonates in the ${ }^{29} \mathrm{Si}$ NMR spectra at ca. $-58 \mathrm{ppm})$. Similarly, negligible interaction is observed in the case of hydride $\left[\mathrm{Pt}(\mathrm{H})\left(\mathrm{I}^{t} \mathrm{Bu}\right)_{2}\right]\left[\mathrm{BAr}^{\mathrm{F}}\right]$ and $\mathrm{Et}_{2} \mathrm{SiH}_{2}$ ( $\mathrm{SiH}$ protons of $\mathrm{Et}_{2} \mathrm{SiH}_{2} 0.2 \mathrm{ppm}$ downfield shifted with respect to the ${ }^{1} \mathrm{H}$ NMR spectrum recorded at $\mathrm{rt}$ ).

All attempts to obtain crystals suitable for X-ray diffraction for the $\sigma-\mathrm{SiH}$ complexes at low temperature failed. Thus, we turned to DFT calculations ((M06/6-31g(d,p) + SDD; see ESI $)^{[18]}$ to analyze the stability and coordination mode of the silanes to complexes 1-3 (Figure 4). According to the calculations, coordination of the silane molecules to complexes 1-3 in a $\sigma-\mathrm{SiH}$ fashion is exothermic in all cases with energy returns in the range -12.8 to $-8.2 \mathrm{kcal} \cdot \mathrm{mol}^{-1}$ (Table S8), which lays within the expected loss of entropy at r.t., ${ }^{[19]}$ and agrees with coordination of the silanes to the metal complexes at temperatures lower than room temperature. Also, the calculations predict a slight preference for the coordination of $\mathrm{Et}_{2} \mathrm{SiH}_{2}$ to all metal fragments and, in agreement with our observations, of both silanes to 1 .
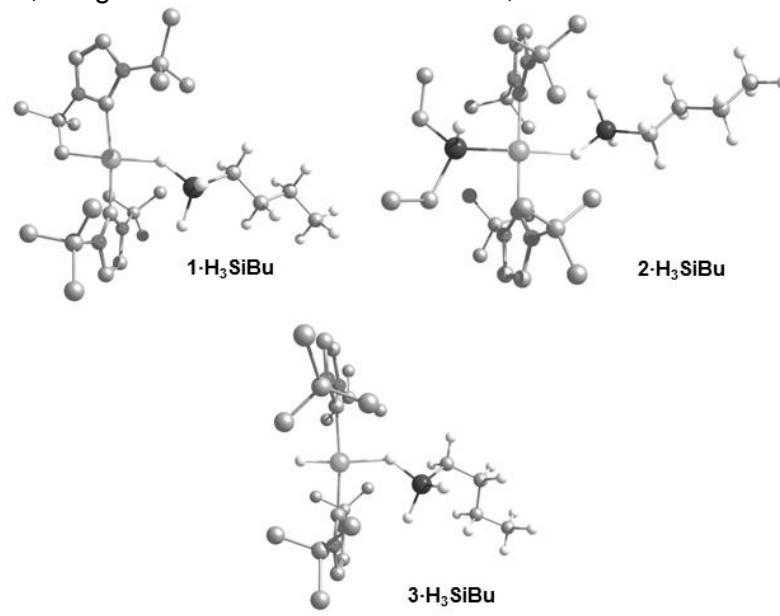

Figure 4. DFT calculated structures of complexes $1-3 \cdot \mathrm{H}_{3} \mathrm{SiBu}$.

The Pt...Si distances (greater than the sum of the covalent radii) and $\mathrm{Pt} \cdots \mathrm{H}-\mathrm{Si}$ angles are consistent with a preferred $\eta^{1}-\mathrm{Si}-\mathrm{H}$ coordination mode, ${ }^{[2]}$ but some differences in the structural parameters have been observed (Table 1). Complex $\mathbf{1}$ is the one that forces to a greater extent the $\eta^{1}$ coordination mode according to the angle defined by the $\mathrm{Pt} \cdots \mathrm{H}-\mathrm{Si}$ atoms and the Pt...Si bond distances (Table 1). This is likely due to the cyclometalated nature of the NHC that, at variance to the noncyclometalated $I^{t} \mathrm{Bu}$ ligands in complexes $\mathbf{2}$ and $\mathbf{3}$, cannot rotate about the $\mathrm{Pt}-\mathrm{C}_{\text {(carbene) }}$ bond to accommodate the silane. The $\mathrm{Pt} \cdots \mathrm{H}$ and $\mathrm{Pt} \cdots \mathrm{Si}$ distances in complexes $\mathbf{2} \cdot \mathrm{H}_{3} \mathrm{SiBu}$ and $\mathbf{2} \cdot \mathrm{H}_{2} \mathrm{SiEt}_{2}$ are considerably longer (see Table 1 ). A closer look at the angles defined by the two carbene carbon atoms and the platinum center hints at a possible explanation. These angles are nearly $182^{\circ}$ for these species, compared to the ca. $175^{\circ}$ in 3. $\mathrm{H}_{3} \mathrm{SiBu}$ and $\mathbf{3} \cdot \mathrm{H}_{2} \mathrm{SiEt}_{2}$, that is, the $\mathrm{Et}_{2} \mathrm{SiH}$ fragment in complexes $\mathbf{2} \cdot \mathbf{H}_{3} \mathrm{SiBu}$ and $\mathbf{2} \cdot \mathbf{H}_{2} \mathbf{S i E t}_{2}$ is pushing the $I^{t} \mathrm{Bu}$ ligands towards the silane, hampering its interaction with the platinum atom. Obviously, the $\mathrm{C}_{\text {(carbene) }}-\mathrm{Pt}-\mathrm{C}_{\text {(carbene) }}$ angles in the

Table 1. Selected structural parameters of the DFT-optimized geometries for the silane adducts.

\begin{tabular}{lccccc}
\hline Complex $^{[a]}$ & $\mathrm{Pt} \cdots \mathrm{H}(\AA)$ & $\mathrm{Pt} \cdots \mathrm{Si}(\AA)$ & $\mathrm{Si} \cdots \mathrm{H}(\AA)$ & $\mathrm{Pt}-\mathrm{H}-\mathrm{Si}\left({ }^{\circ}\right)$ & $\mathrm{C}-\mathrm{Pt}-\mathrm{C}\left(^{\circ}\right)$ \\
\hline $\mathbf{1} \cdot \mathrm{H}_{3} \mathrm{SiBu}$ & 1.96 & 3.33 & 1.53 & 145.25 & 173.28 \\
$\mathbf{2} \cdot \mathrm{H}_{3} \mathrm{SiBu}$ & 2.24 & 3.54 & 1.51 & 140.73 & 182.52 \\
$\mathbf{3} \cdot \mathrm{H}_{3} \mathrm{SiBu}$ & 1.95 & 3.24 & 1.53 & 137.09 & 174.75 \\
$\mathbf{1} \cdot \mathrm{H}_{2} \mathrm{SiEt}_{2}$ & 1.96 & 3.44 & 1.53 & 159.07 & 171.46 \\
$\mathbf{2} \cdot \mathrm{H}_{\mathbf{2}} \mathrm{SiEt}_{2}$ & 2.18 & 3.63 & 1.52 & 157.25 & 182.35 \\
$\mathbf{3} \cdot \mathbf{H}_{\mathbf{2}} \mathrm{SiEt}_{2}$ & 1.94 & 3.39 & 1.53 & 154.81 & 175.45
\end{tabular}

analogous $\mathbf{1} \cdot \mathrm{H}_{3} \mathrm{SiBu}$ and $\mathbf{1} \cdot \mathrm{H}_{2} \mathrm{SiEt}_{2}$ species are enforced to be more acute, but the coplanar disposition of the cyclometalated $\mathrm{NHC}$ ring (with respect to the coordination plane of the platinum atom) orientate the ${ }^{t} \mathrm{Bu}$ group towards the silane. As expected, the NBO analysis (see ESI) indicates the increase in partial positive charge on the silicon atom upon stablishing an interaction with the metal center.

The close relationship of these $\mathrm{Pt}^{\mathrm{I}} \sigma$-SiH complexes and the $\mathrm{Ir}^{\mathrm{III}}$ species reported by Brookhart, prompted us to study the catalytic activity of derivatives 1-3 in $\mathrm{CO}_{2}$ hydrosilation (Scheme 3). Although these complexes are inert in the presence of $\mathrm{CO}_{2},{ }^{[20]}$ catalytic activity was observed in mixtures of silanes and $\mathrm{CO}_{2}$. Complex 1 proved to be the most efficient of the three, while 2 and 3 are quite comparable. When catalyst $1(0.5 \%)$ was reacted with ${ }^{\mathrm{n}} \mathrm{BuSiH}{ }_{3}$ under 5 atm of $\mathrm{CO}_{2}$, a clean reaction took place leading almost exclusively to silylformate ${ }^{\mathrm{n}} \mathrm{BuSiH}_{2}(\mathrm{OCOH})$ in ca. $15 \mathrm{~min}$ at room temperature quantitatively (by NMR). The TON and TOF numbers associated with this transformation are 200 and $714 \mathrm{~h}^{-1}$ (Table S2).

$$
\begin{gathered}
\mathrm{CO}_{2}+\mathrm{RR}^{\prime} \mathrm{SiH}_{2} \underset{\mathrm{CH}_{2} \mathrm{Cl}_{2} / \mathrm{rt}}{\stackrel{[\mathrm{Pt}]_{\mathrm{cat}}}{\longrightarrow}} \mathrm{HR}^{\prime} \mathrm{RSi}-\mathrm{O}^{-} \stackrel{\text { C }}{\mathrm{C}}{ }_{\mathrm{H}} \mathrm{H}, \mathrm{R}^{\prime}={ }^{\mathrm{n}} \mathrm{Bu} ; \mathrm{R}=\mathrm{R}^{\prime}=\mathrm{Et}
\end{gathered}
$$

Scheme 3. Hydrosilation of $\mathrm{CO}_{2}$ catalyzed by complexes 1-3

This result is in stark contrast with the reduction of $\mathrm{CO}_{2}$ using trialkylsilanes catalyzed by the iridium complex $\left[(\mathrm{POCOP}) \operatorname{Ir}(\mathrm{H})\left(\eta^{1}-\mathrm{HSiR}_{3}\right)\right]^{+}$, for which over-reduction to methane was observed, but resembles pretty much that observed by Chen et al. with the aluminium Lewis acid $\mathrm{Al}\left(\mathrm{C}_{6} \mathrm{~F}_{5}\right)_{3}$ in the absence of $\mathrm{B}\left(\mathrm{C}_{6} \mathrm{~F}_{5}\right)_{3}$ as co-catalyst. ${ }^{[9]}$ The selectivity of the process towards the monoformate is also remarkable. In spite of the limited studies on the reduction of $\mathrm{CO}_{2}$ by primary silanes, incorporation of two or even three molecules of carbon dioxide leading to bis- and tris-formates is prevalent in most of the 
cases. ${ }^{[6 a, g]}$. On the other hand, under the same catalytic conditions, complexes 2 and $3(0.5 \%)$ required $10 \mathrm{~h}$ to fully convert ${ }^{\mathrm{n}} \mathrm{BuSiH}_{3}$ into silyl-formate ${ }^{\mathrm{n}} \mathrm{BuSiH}{ }_{2}(\mathrm{OCOH})$. At the end of these catalytic reactions, catalysts 2 and 3 remained intact, while catalyst $\mathbf{1}$ was partially transformed into hydride $\mathbf{3}$ due to the presence of adventitious water.

$\mathrm{PhSiH}_{3}$ was also used for the hydrosilylation of $\mathrm{CO}_{2}$. However, in spite of the presence of silylformate compounds, several other unidentified products were produced.

$\mathrm{Et}_{2} \mathrm{SiH}_{2}$ does also generate the corresponding silylformate $\mathrm{Et}_{2} \mathrm{SiH}(\mathrm{OCOH})$ with catalyst 1. Nevertheless, the reaction proceeded at considerably slower rates in comparison with the reactions carried out with butylsilane and, in addition, higher catalyst loadings (3\%) were required to achieve full conversion after $6 \mathrm{~h}$ at rt. Once more, we have noticed that hydrolysis of $\mathrm{Et}_{2} \mathrm{SiH}_{2}$ with release of $\mathrm{H}_{2}$ is detrimental for the catalytic activity of complex 1 due to formation of the less catalytically active complex 3. Likewise, complexes $\mathbf{2}$ and $\mathbf{3}$ catalyzed the transformation of $\mathrm{Et}_{2} \mathrm{SiH}_{2}$ into $\mathrm{Et}_{2} \mathrm{SiH}(\mathrm{OCOH})$ but very long reaction times were necessary (see Table $\mathrm{S} 2$ ).

In summary, we have detected by NMR the formation of silane $\sigma$-complexes with the highly electrophilic platinum complex 1. According to DFT calculations, the most favored coordination mode is the rare $\eta^{1}-\mathrm{SiH}$ for which only one example has been reported. In one of the cases, the coordination of the silane precedes the $\mathrm{Si}-\mathrm{H}$ bond cleavage leading to the first structurally characterized cationic Pt"-silyl complex $\left[\mathrm{Pt}\left(\mathrm{SiHEt}_{2}\right)\left(\mathrm{I}^{\mathrm{t} B u}\right)_{2}\right]\left[\mathrm{BAr}{ }^{\mathrm{F}}\right]$, 2. The interaction of the silanes with the platinum atom depends strongly on the orientation of the $\mathrm{NHC}$ with respect to the metal center, being more favored when is cyclometalated. The enhanced electrophilicity of the silicon atom in the silane through its coordination to platinum (in a similar way than the iridium complex reported by Brookhart) makes it reactive enough to hydrosilate $\mathrm{CO}_{2}$ in a selective way towards mono-silylformates. Ongoing efforts are geared toward crystallographical characterization of a $\sigma$-SiH platinum complex and understanding the mechanism for the hydrosilation of $\mathrm{CO}_{2}$.

\section{Acknowledgements}

Financial support (FEDER contribution) from the MINECO (Projects CTQ2013-45011-P and CTQ2014-51912-REDC) and the Junta de Andalucía (Project FQM-2126) is gratefully acknowledged. P.R. thanks the Junta de Andalucía for a research grant.

Keywords: Platinum • Carbon Dioxide $•$ Silane $\cdot \sigma$-complex $•$ Hydrosilation

[1] a) J. Y. Corey, Chem. Rev. 2011,111, 863-1071; b) G. I. Nikonov, Adv. Organomet. Chem. 2005, 53, 217-309; c) G. Alcaraz, S. Sabo-Etienne, Eur. J. Inorg. Chem. 2006, 2115-2127.

[2] a) M. C. Lipke, T. D. Tilley, J. Am. Chem. Soc. 2011, 133, 16374-16377; b) S. Park, M. Brookhart, J. Am. Chem. Soc. 2012, 134 640-653; c) D. V. Gutsulyak, G. I. Nikonov, Angew. Chem. 2010, 122, 7715-7718; Angew. Chem. Int. Ed. 2010, 49, 7553-7556; d) J. Yang, P. S. White, C. K. Schauer, M. Brookhart, Angew. Chem. 2008, 120, 4209-4211; Angew. Chem. Int. Ed. 2008, 47, 4141-4143; e) S. L.
Matthews, V. Pons, D. M. Heinekey, Inorg. Chem. 2006, 45 6453-6459; f) X.-L. Luo, R. H. Crabtree, J. Am. Chem. Soc. 1989, 111 2527-2535. For examples of main group $\eta^{1}-\mathrm{SiH}$ complexes see: $\mathrm{g}$ ) J. Chen. E. Y.-X. Chen. Angew. Chem. 2015, 127, 6946-6950; Angew. Chem. Int. Ed. 2015, 54, 6842-6846; h) A. Y. Houghton, J. Hurmalainen, A. Mansikkamäki, W. E. Piers, H. M. Tuononen, Nat. Chem. 2014, 6, 983-988; i) S.P. Hoffmann, T. Kato, F. S. Tham, C. A. Reed, Chem. Commun. 2006, 767-769.

[3] a) V. H. Mai, I. Korobkov, G. I. Nikonov, Organometallics 2016, 35, 936-942; b) M. D. Doherty, B. Grant, P. S. White, M. Brookhart Organometallics 2007, 26, 5950-5960; c) F. L. Taw, R. G. Bergman, M. Brookhart, Organometallics 2004, 23, 886-890; d) S. T. N. Freeman, F .R. Lemke, Organometallics 2002, 21, 2030-2032; e) X. Fang, B. L. Scott, K. D. John, G. J. Kubas, Organometallics 2000, 19, 4141-4149; f) E. Scharrer, S. Chang, M. Brookhart, Organometallics 1995, 14, 5686-5694; g) F. R. Lemke, J. Am. Chem. Soc. 1994, 116, 11183-11184

[4] a) S. Park, D. Bézier, M. Brookhart, J. Am. Chem. Soc. 2012, 134, 11404-11407; b) S. J. Mitton, L. Turculet, Chem. Eur. J. 2012, 18, 15258-15262; c) R. Lalrempuia, M. Iglesias, V. Polo, P. J. Sanz Miguel, F. J. Fernández-Alvarez, J. J. Pérez-Torrente, L. A. Oro, Angew. Chem. 2012, 124, 12996-12999; Angew. Chem. Int. Ed. 2012, 51, 12824 12827; d) P. Deglmann, E. Ember, P. Hofmann, S. Pitter, O. Walter, Chem. Eur. J. 2007, 13, 2864-2879.

[5] a) Q. Liu, L. Wu, R. Jackstell, M. Beller, Nat. Commun. 2011, 6, 1-15; b) F. J. Fernández-Alvarez, A. M. Aitanib, L. A. Oro, ChemCatChem 2014, 4, 611-624

[6] a) M. L. Scheuermann, S. P. Semproni, I. Pappas, P. J. Chirik, Inorg Chem. 2014, 53, 9463-9465. b) L. González-Sebastián, M. FloresAlamo, J. J. García, Organometallics 2013, 32, 7186-7194; c) L. Zhang, J. Cheng, Z. Hou, Chem. Commun. 2013, 49, 4782-4784; d) S. Itagaki, K. Yamaguchi, N. Mizuno, J. Mol. Catal. A: Chem. 2013, 366, 347-352; e) K. Motokura, D. Kashiwame, N. Takahashi, A. Miyaji, T. Baba, Chem. Eur. J. 2013, 19, 10030-10037; f) K. Motokura, D. Kashiwame, A. Miyaji, T. Baba, Org. Lett. 2012, 14, 2642-2645; g) A. Jansen, H. Gorls, S. Pitter, Organometallics 2000, 19, 135-138; h) H. Koinuma, F. Kawakami, H. Kato, H. Hirai, J. Chem. Soc., Chem. Commun. 1981, 213-214.

[7] a) P. Ríos, N. Curado, J. López-Serrano, A. Rodríguez, Chem. Commun. 2016, 52, 2114-2117; b) T. T. Metsänen, M. Oestreich, Organometallics 2015, 34, 543-546; c) F. A. LeBlanc, W. E. Piers, M. Parvez, Angew. Chem. 2014, 126, 808-811; Angew. Chem. Int. Ed. 2014, 53, 789-792; d) Y. Jiang, O. Blacque, T. Fox, H. Berke, J. Am. Chem. Soc. 2013, 135, 7751-7760.

[8] a) S. N. Riduan, Y. Zhang, J. Y. Ying, Angew. Chem. 2009, 121 3372-3375; Angew. Chem. Int. Ed. 2009, 48, 3322-3325; b) T. C. Eisenschmid, R. Eisenberg, Organometallics 1989, 8, 1822-1824.

[9] a) J. Chen, L. Falivene, L. Caporaso, L. Cavallo, E. Y.-X. Chen, J. Am. Chem. Soc. 2016, 138, 5321-5333; b) R. J. Wehmschulte, M. Saleh, D. R. Powell, Organometallics 2013, 32, 6812-6819; c) S. J. Mitton, L. Turculet, Chem. Eur. J. 2012, 18, 15258-15262; d) M. Khandelwal, R. J. Wehmschulte, Angew. Chem. 2012, 124, 7435-7439; Angew. Chem. Int. Ed. 2012, 51, 7323-7326; e) A. Berkefeld, W. E. Piers, M. Parvez, J. Am. Chem. Soc. 2010, 132, 10660-10661; f) T. Matsuo, H. Kawaguchi, J. Am. Chem. Soc. 2006, 128, 12362-12363.

[10] A. Schäfer, W. Saak, D. Haase, T. Müller, Angew. Chem. 2012, 124 3035-3038; Angew. Chem. Int. Ed. 2012, 51, 2981-2984.

[11] T. Robert, M. Oestreich, Angew. Chem. 2013, 125, 5324-5326; Angew. Chem. Int. Ed. 2013, 52, 5216-5218.

[12] O. Rivada-Wheelaghan, B. Donnadieu, C. Maya, S. Conejero, Chem. Eur. J. 2010, 16, 10323.

[13] a) M. Roselló-Merino, R. J. Rama, J. Díez, S. Conejero, Chem Commun. 2016, 52, 8389-8392; b) M. Roselló-Merino, J. LópezSerrano, S. Conejero, J. Am. Chem. Soc. 2013, 135, 10910-10913.

[14] M. A. Ortuño, S. Conejero, A. Lledós, Beilstein J. Org. Chem. 2013, 9, 1352-1382. 
[15] O. Rivada-Wheelaghan, M. Roselló-Merino, M. A. Ortuño, P. Vidossich, E. Gutiérrez-Puebla, A. Lledós, S. Conejero, Inorg. Chem. 2014, 53 4257-4268.

[16] a) M. Besora, F. Maseras, A. Lledós, O. Eisenstein, Inorg. Chem. 2002, 41, 7105-7112; b) G. P. Mitchell, T. D. Tilley, Angew. Chem. 1998, 110, 2602-2605; Angew. Chem. Int. Ed. 1998, 37, 2524-2526.
[17] J. C. DeMott, W. Gu, B. J. McCulloch, D. E. Herbert, M. D. Goshert, J. R. Walensky, J. Zhou, O. V. Ozerov, Organometallics 2015, 34 3930-3933.

[18] For results using PBE0, PBE0-D3 and wb97XD functionals see ESI.

[19] L. A. Watson, O. Eisenstein, J. Chem. Educ., 2002, 79, 1269-1277.

[20] M. Devillard, R. Declercq, E. Nicolas, A. W. Ehlers, J. Backs, N. SaffonMerceron, G. Bouhadir, J. C. Slootweg, Werner Uhl, D. Bourissou, J. Am. Chem. Soc. 2016, 138, 4917-4926. 
Entry for the Table of Contents (Please choose one layout)

Layout 1:

\section{COMMUNICATION}

$\eta^{1}$-SiH platinum complexes are intermediates in the hydrosilation of carbon dioxide.
Pablo Ríos, Josefina Díez, Joaquín López-Serrano, Amor Rodríguez*, Salvador Conejero*

Page No. - Page No.

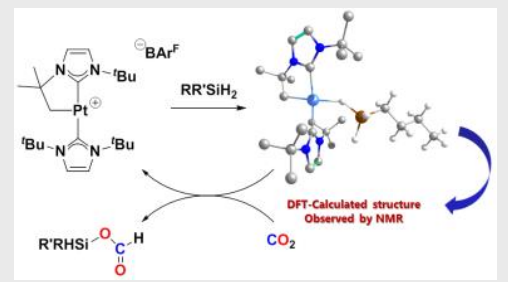

Title 